\title{
Britain's Crimean War Trophy Guns: The Case of Ludlow and the Marches
}

\author{
ROGER BARTLETT \\ University College London \\ ROY PAYNE \\ Ludlow History Research Group
}

\begin{abstract}
Many of the numerous monumental cannon which adorn British cities are Crimean War trophies: something little discussed in the historiography of the war. Focusing on the trophy cannon at Ludlow, in the Welsh Marches, the article looks at both the national and the local scene. It describes first the Allied operation in Sevastopol to gather prize Russian cannon and their removal to England. The utility of shipping the guns home and the uses to which they might be put were both controversial, but whether intact or melted down the cannon formed a significant part of the multifarious memorials and mementos generated by the war and Allied victory. The focus then switches to the Marches and the acquisition of trophy guns by Ludlow and neighbouring towns; the political background to Ludlow's application for a cannon is also explored, and the subsequent fate of the region's prize guns. Finally the article examines the origins of the Ludlow cannon and the identity of its founder, a British expatriate ironmaster working in Russia at the turn of the eighteenth century.
\end{abstract}

\section{I}

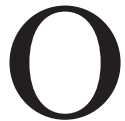

utside the gates of Ludlow Castle, in the Welsh Marches, stands a large iron cannon. The plaque on the carriage states 'Captured 1855 at Sevastopol': a trophy of the Crimean War, 1853-6. The war gave us the Victoria Cross, Florence Nightingale and Mary Seacole, the Charge of the Light Brigade and the Thin Red Line (of the Sutherland Highlanders). It also gave us the dozens of Russian trophy cannon which still adorn towns and cities across Britain, Ireland and the former Dominions.

Hostilities between Turkey, Britain, France and their allies, and Russia, took place in widely different theatres, but the main focus of the Crimean War became the Allied siege of the principal Russian naval base on the Black Sea, Sevastopol. The siege lasted over a year, and the besiegers by no means had everything their own way. They had

An early version of this article was read to the Ludlow Civic Society as the Society's 2011 Fred Reeves Memorial Lecture. 
insufficient troops to isolate the city from its hinterland, so that the Russians, under the brilliant leadership of General Eduard Todleben, were able to bring up regular reserves and reinforcements. According to Capt. Edmund Reilly's official account of British artillery operations, ${ }^{1}$

To arm the [gun] batteries which the enemy constructed where he wished, he had a great Arsenal, a Dockyard and a Fleet, capable not only of supplying his first armament, but also of replacing his guns as soon as disabled. He had at hand an almost unlimited quantity of matériel and supply of labour to repair and strengthen the works which we were called upon to destroy; and the place not being invested, matériel brought from a distance became available for its defence, while the garrison could be continually relieved.

To the last hour of the Siege the enemy continued enlarging his batteries, and constructing new ones, nor was he ever deficient in ordnance to arm them. Three thousand pieces which had not been mounted were taken in the place.

This unfailing supply of artillery was one of the chief causes of the protracted defence.

The town was shattered by the prolonged Anglo-French cannonade, but the Russian fortresses and fortifications held out and the Allies finally decided on a frontal attack. On 8 September 1855 the French assaulted and took the key to the Russian defensive position, the Malakhov redoubt. The simultaneous British assault on the neighbouring redoubt, the Redan, failed; but that night the Russians evacuated the south side of Sevastopol, retreating to impregnable positions on the north. As far as Sevastopol was concerned, the event was decisive: the Allies gained control of the town and harbour, shipyards and fortifications, and with them vast amounts of stores and ordnance. A British eye-witness participant, Lt-Col. Richard Kelly, even 'heard a report that the Commission has valued the English share of the guns and stores taken at Sebastopol at a year's pay for the whole army' - although he was sceptical about this rumour. ${ }^{2}$

The war was ended by the Treaty of Paris of 30 March 1856. As peace came closer, the Allies prepared to withdraw their troops and materiel, including the spoils of war. The Allied commanders were keen to neutralize Sevastopol's military capacity, but also to salvage what they could. Initially, the logistical difficulties of bringing home prize guns seem to have weighed more heavily, both with the British Crimean command and with the Secretary for War in London, than their value,

\footnotetext{
1 An Account of the Artillery Operations conducted by the Royal Artillery and Royal Naval Brigade before Sebastopol in 1854 and 1855. Compiled by W. Edmund M. Reilly, C.B., Captain, Royal Artillery, and Brevet-Major (Late Brigade-Major of the Siege Train) (London, 1859) [hereafter Reilly, Account], p. 201.

${ }^{2}$ An Officer's Letters to his Wife during the Crimean War. With an Introductory Memoir of General Sir Richard Denis Kelly, K. C.B. By his daughter, Mrs W. J. Tait (London, 1902) [hereafter Officer's Letters], p. 354.
} 
real or symbolic. Early in February 1856 the then British commanderin-chief in the Crimea, Sir William Codrington, cabled to the Secretary for War, Fox Maule, Lord Panmure, to request instructions about captured Russian ordnance. He had already sent home some captured bells and brass cannon and wished to send more, but was dubious about the trouble and costs involved.

I should be glad to know the opinion about guns, Russian guns. I propose sending home several from the Redan, wounded and damaged, with their carriages, and many good ones from the gun wharf. ... We have now about forty guns up on the plateau, which I wished to have ready for possible ulterior purposes here near Balaclava: these can go home if there is peace. I can get the whole, carronades ${ }^{3}$ and all sorts which are of no artillery value; but it will be a long job, and somewhat tear the horses about, which are of more value than the guns. If you wish no gun to be left on the ground, I can do so: if you prefer their destruction, and throwing into the water, I can do so ...4

Panmure doubted the wisdom of expending effort on prize cannon. He confided to Codrington:

I have not yet confidence in Peace. I see many rocks ahead which it is difficult to describe, and, whatever our Allies may do, you must go on preparing for offensive operations until you receive positive orders to hold your hand. ... I have got home your brass trophies; in regard to the others, I have telegraphed to you to destroy them and throw them into the harbour. If you can save any of the best you may, but it is of no great consequence. $^{5}$

Lord Palmerston agreed with the Secretary for War. ${ }^{6}$

While London was lukewarm about trophies, the Army in the Crimea nevertheless set about retrieving as many Russian guns as possible. With peace not settled, Codrington still kept some enemy ordnance ready for battle-field use. ${ }^{7}$ Lt-Col. Kelly in his letters home recorded difficulties, adding:

The French have removed almost all the guns from their share of the works, but the greater part of ours still remain in the embrasures; we are, however, beginning to think seriously of removing them, and as a first step our regiment has been selected to make a road from the Redan to the Worontsoff road, about two miles, for the artillery waggons to travel on. ${ }^{8}$

3 See p. 668.

4 The Panmure Papers, being a selection from the correspondence of Fox Maule, second Baron Panmure, afterwards eleventh Earl of Dalhousie, KT, GCB, ed. Sir George Douglas, Bart, MA and Sir George Dalhousie Ramsay, CB, late of the War Office, 2 vols (London, 1908) [hereafter PP], II, 90.

5 PP, II, 94.

6 PP, II, 92.

7 PP, II, 106-7.

8 Officer's Letters, pp. 363, 401, 402.

(C) 2014 The Authors. History published by The Historical Association and John Wiley \& Sons Ltd 
Codrington reported on 16 February to Panmure that he was taking advantage of good weather 'to put the Artillery strength upon the Russian guns, of which 125 are away from the town, 106 being on this plateau near the rail, 11 at Balaclava, and 8 embarked in the Edward'. $\mathrm{He}$ also wanted to ensure that no disabled British guns were left to become Russian prizes. ${ }^{9}$ Panmure concurred, again urging that such guns should be sunk beyond recovery, in deep water. ${ }^{10}$

Meanwhile Kelly's road-building had been a great success and brought him compliments from on high. '[The road] has been made', he repeated to his wife on 17 February,

to facilitate the getting of the Russian guns, etc, out of the Redan, for the artillery are to begin in earnest at that work tomorrow, as they say that there are nearly 1000 guns to be shipped for England, and part at Balaklava and part at Kazataev [Kazatch?], to which latter place a brigade of the 4th Division is to be sent immediately to construct wharves. In the Redan yesterday the artillery were busy unspiking the Russian guns, and either drawing the charges or firing them off into the parapet. ${ }^{11}$

While peace slowly drew closer, Codrington's instructions were still to maintain a war footing. Panmure's cable of 25 February announcing the opening of the peace conference also noted: 'The Queen has seen your trophies and has already found place for the two great bells, which took her fancy amazingly. The guns are poor things, but they are valuable as spoils of war.'

As March arrived, the message was the same - prepare for war while peace is negotiated - though Panmure approved of the initial actions of the Allies in destroying Russian fortifications and gathering captured guns. ${ }^{12}$ The Allies were glad to use the destruction of the fortifications for experiments with explosive techniques. One structure destroyed in this way was the spectacular dry docks only recently completed by the expatriate British engineer John Upton. ${ }^{13}$ Fifteen years in construction, they became operational in 1851, and were dynamited in 1856 .

Then momentum at the peace negotiations became unstoppable: Panmure heralded 'this sudden peace' and turned his attention to getting British forces - and their spoils - home to Britain. ${ }^{14}$ Codrington reported on 8 March on work required to salvage the guns:

\footnotetext{
9 PP, II, 106-7.

$10 P P$, II, 139.

11 Officer's Letters, pp. 404-5.

12 PP, II, 129, 139.

13 [G. Dodd], Pictorial History of the Russian War 1854-56, with Maps, Plans and Wood Engravings (Edinburgh-London, 1856), p. 232. Upton: Yu. and E. Kulikov, C. Robins, 'The Sevastopol Docks, and Upton - traitor or honourable man?', The War Correspondent, 28/1 (2010), pp. 28-34; Michael Vanden Bosch and Roger Bartlett, 'More Light on the Upton Family in Russia and the Crimean War', The War Correspondent, $29 / 2$ (2011), p. 9:, 30/1 (2012), pp. 26-32; 30/3 (2012), pp. $10-19$.

${ }^{14} P P$, II, 145-6.
}

(C) 2014 The Authors. History published by The Historical Association and John Wiley \& Sons Ltd 
In order to move the Russian guns both from the gun wharf and creek batteries on the level of the water, and from the Redan and Barrack batteries, the Woronzoff road was repaired by a detachment of the Army Works Corps, and openings were made through the rampart and across the ditch of the proper left face of the Redan. The greater part of the Artillery horses have been daily employed during decent weather in this: it is a heavy business, but 406 guns or carronades have already been put on board of ship for England: the detail of what they are will go home, of course, to Woolwich. There are many of the Redan guns which, with their carriages, showing the knocking about of shot upon them, I thought might be interesting; and one or two big mortars also. ${ }^{15}$

Ten days later, Panmure's cable was concerned with the practicalities of withdrawal, and still inclined not to bother with any but usable or superior brass guns. 'All the heavy and serviceable siege guns can be packed at Malta and Gibraltar, and I venture once more to suggest to you that all unserviceable iron ordnance should be carried in lighters outside the harbour of Balaclava and there consigned to the deep.'16 Other items could be shipped out. The official 'Return of Russian Stores ... Shipped by the British Army for England', drawn up by Captain Reilly, included a vast array of equipment. ${ }^{17}$ And despite Panmure's exhortations, most of the weapons were dealt with similarly. A special Anglo-French commission was set up to share out the captured materiel. ${ }^{18}$ The French were keen to offset the captured Napoleonic cannon from 1812 which were (and still are) displayed in the Moscow Kremlin: Codrington noted that 'the French are moving any number [of guns] for the purpose of making a "Boulevard Sebastopol," as a pendant to the French guns at Moscow.' ${ }^{19}$ Kelly saw the wharves at Kamiesch, the French Crimean base, 'covered with Russian guns and anchors ready for shipment to France'. ${ }^{20}$ Just at this time Baron Haussman was reshaping the centre of Paris; his great new north-south axis, initially called Boulevard du Centre, was renamed for Sevastopol. The Boulevard de Sébastopol still runs through the centre of Paris, although without any prize cannon. (Napoleon III gave 213 French iron prize guns for the casting of the vast statue of the Virgin, 'Notre Dame de France', at Le Puy-en-Velay, Auvergne, completed in 1860.)

The most valued guns were brass or bronze, and the Allies made an exact division - according to Reilly, of 177 captured bronze pieces, the French received 88 and the British 89 . Iron ordnance was less valuable and more plentiful: Reilly recorded a total of 875 iron pieces shipped back to Britain. (The Times gave figures of 94 bronze and 1,079 iron

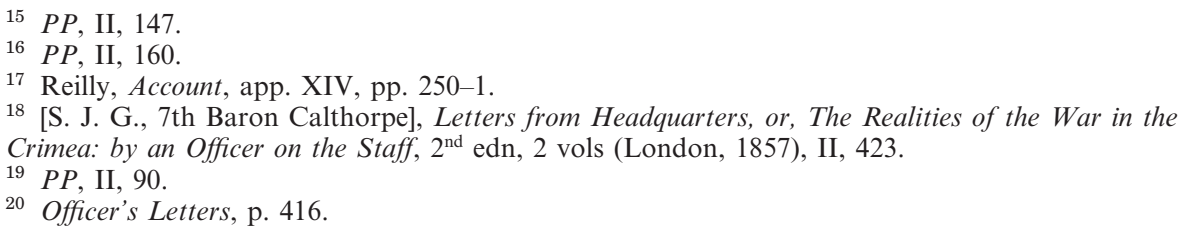


guns, presumably including pieces captured elsewhere. ${ }^{21}$ ) Ten bells were also sent home. ${ }^{22}$ Panmure's cables continued lukewarm about trophies in general: 'We have no desire to have a "boulevard Sebastopol", but a few reminiscences of our long siege will be acceptable. ${ }^{23}$ By this time, more Sevastopol guns were reaching London. They were sent to the Woolwich Arsenal, where they joined guns captured in Britain's Baltic naval actions, landed shortly before. ${ }^{24}$ A report from Woolwich of 23 February 1856 described how

Several guns and mortars, and two large bells brought from Sebastopol, have been added to the Hango trophies of the war. They are deposited at the entrance of the Arsenal grounds; some of them are heavy iron guns of large calibre, and of a most singular appearance. The ornamentation of the bells, which bear representations of saints, is tastefully executed. . . On Tuesday last the Queen and Prince Albert ... viewed the cannon, mortars and other articles captured in the Crimea and at Bomarsund. The Queen afterwards inspected, in the Committee room, a number of wounded soldiers, recently returned invalided from the seat of the war. ${ }^{25}$

The queen also ordered that the usual tight security at Woolwich be relaxed to admit members of the public wishing to see the trophies: The Times recorded great public curiosity. Victoria wished in addition to have mementos of her meeting with the veterans, and sent her household photographer, J. E. Mayall, to 'produce several groups of faces and whatever he should consider most interesting' ${ }^{26}$

The value of the guns as symbols, both of dominance over a defeated enemy and of alliance in wartime, was further demonstrated in the distribution of spoils to Sardinia, valiant junior coalition partner. ${ }^{27}$ The Sardinians received some 200 iron guns, including a gift of six British cannon with which they had fought in the war. Codrington, 'hearing . . . that they would be very glad to have them as part of their share of the Russian guns', thought it 'much better to offer them from the English Government as a souvenir to them of the Alliance'. ${ }^{28}$ An allocation of brass Russian trophies from the British share should be made to Sardinia later. At the same time Panmure himself was hoping for an Ottoman cannon as a monument to the Anglo-Turkish fellowship of the war; he wrote to Lord Clarendon, Secretary of State for Foreign Affairs

21 The Times, 13 May 1858, p. 12.

22 Reilly, Account, app. XI no. 3; app. XII, pp. 248-9; app. XV, p. 251.

23 PP, II, 106.

24 'Hango trophies at Woolwich Arsenal', The Illustrated London News [hereafter ILN] (courtesy Jennifer Griffiths and The Illustrated London News Historical Archive, Gale Publishing), no. 748, 9 Feb. 1856, p. 148.

25 'Russian Guns and Bells at Woolwich ...', in: R. E. White, Recollections of Woolwich during the Crimean War and Indian Mutiny and of the Ordnance and War Departments ..., etc. (London, 1885), pp. 30-1, reprinted from $I L N$, no. 786, 23 Feb. 1856, p. 209.

26 The Times, 21 Feb. 1856, p. 12; 25 Feb. 1856, p. 10. Cf. ILN, no. 787, 1 March 1856, p. 225.

$27 P P$, II, 162.

28 PP, II, 185.

(C) 2014 The Authors. History published by The Historical Association and John Wiley \& Sons Ltd 
and plenipotentiary at the Paris peace talks: 'If you could coax Ali to give us one of the large brass ordnance, either from Dardanelles or Smyrna, as a memento of our war alliance, it will be gratefully received. ${ }^{29}$ Clarendon was evidently successful: in April 1857 Panmure informed the queen that 'a fine brass gun on a suitable carriage has arrived from Turkey in YMS Sphinx, ... a a present from the Sultan to Your Majesty, in commemoration of the late war. ${ }^{30}$

Meanwhile news of the war's end was received enthusiastically at home. Streets and public houses were named after Allied Crimean victories. Entrepreneurs offered picture shows such as 'Burford's Panorama of the Fall and Interior of the City of Sebastopol' (in Leicester Square); Mme Tussaud's had been quick to mount wax figures of principal personages of the war. ${ }^{31}$ Proposals for the captured cannon started to reach the government. Codrington himself thought that senior officers should each have a personal piece of ordnance, including the family of the late Lord Raglan. ${ }^{32}$ Raglan's family duly received a bronze cannon and a yedinorog (licorne, howitzer), subsequently displayed at the family estate near Usk. ${ }^{33}$

However, apart from awards to senior officers, the authorities could not immediately decide what to do with the prize guns. They lay in store at Woolwich Arsenal, and over the summer of 1856 no decision was taken. The press wondered at the delay: one report claimed that they were to be 'cut up' and 'mixed with British gun-metal for smelting purposes' ${ }^{34}$ With the British army returned to England, and no resolution on the guns forthcoming, the question of their value, real or symbolic, continued to exercise Codrington, as commander of the fighting men who had suffered the intensity of the war. In October 1856, incensed by a copied War Department letter, he complained to the War Minister:

it is mentioned that the Queen has selected two large bells, and 'that none of the other trophies are of much value'.

This does not portend much consideration for them; and, as I have had so much free communication with you, I hesitate not in putting in a word as to the value of these trophies. We who were engaged in the Crimea may naturally feel that they were of value - that they are not lumbering old stores - and that there is something more in them than the metal of which they are composed. There must have been more than 30 brass pieces of ordnance - our share of what was taken at the fall of Sebastopol; and there were besides 12 field-pieces and their carriages recovered from below the water.

$29 P P$, II, 169.

30 PP, II, 377.

31 Advertised in The Times, 4 and 27 March et al. 1856.

32 PP, II, 185-6.

${ }^{33}$ Christie's Sale Catalogue, no. 4138, April 2012, 'The Raglans, Waterloo, Wellington and the Crimea'; The War Correspondent, 30/1 (2012), pp. 4, 44.

34 The Times, 19 May 1856, p. 10. 
Moreover such guns, valuable as they were, had less significance than weapons captured in battle: 'But there are - or there were - two brass pieces of a very different character, viz., a long 16 pounder gun, and a 32 pounder howitzer, both of which were taken in fair fight in the Battle of the Alma.' Codrington gave a detailed account of how he had witnessed the capture of these particular guns, adding:

Every soldier must hope that these at all events will not be classed with old stores, and got rid of or melted. We may feel pretty sure that the Russians will cherish the possession of the seven English siege guns although of iron - which they took in the Redoubts of Balaclava.

Let us at all events keep - we might even honour - these tangible trophies of the first and brilliant fight of the campaign; nor, indeed, need we be ashamed to park the guns and carriages of the others, as long as the wood and green paint will hold together.

It was not only guns which acquired symbolic value as trophies: others besides Queen Victoria were eager to keep captured bells. Codrington continued:

There was a bell belonging to the 77th regiment, of which I had (to their great disgust) to order the surrender, that it might be sent home with the others; it was obtained by them from the French, and, if possible, I myself would willingly pay the value of it, could I have the pleasure of restoring it; indeed there is not a regiment, or a corps, that would not gladly have, or buy, some such trophy, if there is any idea of their being melted or disregarded.

Codrington ended his plea: 'You may feel that all this is none of my business now, and possibly the expression which I have quoted may mean only a money value.' He hoped, though, for Panmure's agreement that the guns 'have much more than a money value, and are worth retaining in their present shape', ${ }^{35}$

Panmure hastened to reassure the former commander-in-chief. The value referred to was monetary, not 'national', and there was no intention of melting down the guns. 'I am averse to follow the French fashion and to parade the fruits of our conquest, and so keep open the sores of war after the healing hand of peace has been applied. On the other hand, no trophies should be destroyed, but carefully preserved as National Mementos.' The cannon Codrington referred to were safe in the Arsenal; the 77th's bell was probably also there, and could be returned to the regiment. 'The final disposal, either in the Tower or Woolwich, or some public place, of all our guns is yet to be determined, but rely on no dishonour falling on what has cost the Army such exertions to earn. ${ }^{36}$

The problem of what do with the guns rumbled on. Three months later, in January 1857, Panmure was still cautious about further

35 PP, II, 307-8.

36 PP, II, 309.

(C) 2014 The Authors. History published by The Historical Association and John Wiley \& Sons Ltd 
disposals, writing to Victoria: 'Lord Panmure further transmits to Your Majesty a list of all the Russian guns, etc., received at the Royal Arsenal. Suggestions are made for the disposal of many of these trophies, but Lord Panmure does not at present propose to Your Majesty to give any sanction to them.' However, he approved of a government suggestion to share the trophies with Britons at large: 'The Cabinet is of opinion that small numbers of iron ordnance may be granted to such cities or towns in Great Britain and Ireland as have proper public places to put them in, and make application for them, and to this extent Lord Panmure craves Your Majesty's concurrence. ${ }^{37}$

Victoria thought this a good idea, though her reply emphasized the distinction between plebeian iron and noble military brass. She wished bells to be sent to the three British capital cities, Edinburgh, Dublin and London, and brass guns to major naval bases. ${ }^{38}$ Panmure had to point out difficulties with the bells: those remaining were small and damaged 'and would answer no useful purpose anywhere except to exhibit as curiosities'. But he loyally concurred with the other royal wishes: 'Lord Panmure will duly attend to Your Majesty's views as to the brass ordnance, and have lists made out for their distribution to the different forts of importance. ${ }^{39}$

So finally in January 1857 the authorities settled upon a solution to the problem of the captured artillery, with a plan to distribute Crimean trophy guns to British military and naval establishments and to deserving or desirous British and Irish towns and cities 'having room to contain them'. There are records of nearly 300 cannon distributed in this way across the British Isles and to British dominions and dependencies - Australia, Canada, Gibraltar, New Zealand. ${ }^{40}$

Despite Codrington's impassioned advocacy, some guns were melted down to make other forms of memorial. Besides prize cannon, the Crimean War generated monuments and memorabilia of all sorts. A picture of Hangö trophy guns engraved by the Illustrated London News, for instance, also included a Russian sentry box, seized by a British raiding party and destined for a private estate in Sussex. ${ }^{41}$ Soldiers on the ground in the Crimea eagerly gathered mementos. Lt-Col. Kelly

\footnotetext{
37 PP, II, 335.

38 PP, II, 337.

39 PP, II, 340.
}

40 A survey of Crimean trophy guns is being carried out by Major Colin Robins of the Crimean War Research Society. Jana L. Bara, 'Russian artillery: the political and commercial background of the eighteenth-century Anglo-Russian relationship and its results', Arms Collecting, 23/2 (1985), pp. 43-9, is unreliable in historical detail. R. H. Billett, 'Australia's trophies from the Crimean War', Sabretache, 38/1 (1997), was unavailable to us. The latest contributions are Ruth Rhynas Brown, 'Cannon to the right of them, Cannon to the left of them, Cannon in front of them: the Crimean trophy guns in Britain and its empire', ICOMAM Magazine, Issue 11 (Feb. 2014), pp. 26-32, <http://www.icomam.be/magazine.php> (accessed 12 July 2014), which came too late to be used here; Flickr, The Crimea Cannon Pool, <http://www.flickr.com/groups/1604220@N23/> (accessed 12 July 2014).

41 See n. 24. 
described British and Russian troops exchanging or buying objects by wrapping items and coins in clay and throwing them to each other across the Chernaia river. 'Any rubbish coming from Russia is now prized', he wrote. He himself had amassed an extensive collection of 'relics', including 'a Russian officer's chair with handsome plate'. Another letter described 'some of my Russian trophies, which are a soldier's helmet, an officer's shako, three soldiers' swords of different sorts, a small painting of three very warlike looking saints, taken from a house in the town, and lots of bullets, grape-shot and buttons'; a silver medal would be sent home separately for safety's sake. ${ }^{42}$

Another item engraved by the Illustrated London News was a curious trophy collection commissioned by Codrington himself and presented to the queen.

In front are four 13-inch shells, which were recovered from the harbour of Sebastopol. Upon them is placed a large wheel, the part of a hydraulic press found in the dockyard. Above is a mitre wheel from some machinery, surmounted by a 13-inch shell - a smaller shot and shell. In the background is a capstan with a brass top taken out of a vessel sunk near the Dockyard Quay.

The $I L N$ thought this 'an exceedingly pleasing arrangement' ${ }^{43}$ The $I L N$ likewise reproduced one of a series of photographs commissioned by the queen herself: it depicted Crimean veterans with a captured Russian gun and religious banners.

Titled Crimean Heroes and Trophies and presented as an album and an exhibition, the commission was Queen Victoria's response to reports in The Times of disaster in the region, and to the personal stories of suffering supported in part by the first ever photographs from a war zone then filtering back from the Black Sea. ${ }^{44}$

The melted cannon were used in various projects, most notably John Bell's London Crimean War Memorial located on Waterloo Place, near Piccadilly. It was unveiled in 1861, consisting of the statues of three Guardsmen, with a female allegorical figure known as Honour (it was reworked in 1914). William Theed's 1858 statue of Isaac Newton in the latter's home town of Grantham is made from Crimean gun-metal, as is the bronze bell of St Mary's Church, Catherston Leweston, Dorset, built in 1858. According to The Times, a 15-foot bronze obelisk was cast from captured gun-metal for a memorial to the Royal Regiment of Artillery, to be sited at the Woolwich Arsenal; but this was disapproved and stopped by the government. ${ }^{45}$ However, at the end of 1858 a

\footnotetext{
42 Officer's Letters, pp. 310-20, 364-5, 431.

43 'Sebastopol trophies', ILN, no. 833, 6 Dec. 1856, p. 566.

44 'The light shone and was spent: Robert Howlett and the power of photography', PhotoHistories, The Photographers' History of Photography, 30 Jan. 2012, <http://www.photohistories.com/PhotoHistories/51/robert-howlett-and-the-power-of-photography?pg=all> (accessed $31 \mathrm{Jan} .2012$ ).

45 The Times, 13 May 1858, p. 12.
} 
'demi-bust and plate, ordered to be cast from Russian gun-metal in the brass-gun foundry of the Royal Arsenal at Woolwich, representing the crowned head of her Majesty', was erected there; ${ }^{46}$ and in 1860 a Crimean memorial, also cast from Russian cannon, to a design by John Bell, was raised on the edge of the parade ground on Woolwich Common. ${ }^{47}$ Another important use for the captured cannon was to provide metal for the new order of valour, the Victoria Cross, established by Queen Victoria in 1856 and first awarded to meritorious Crimean veterans: the bronze from which the crosses were cast was taken from the cascabel of a captured brass gun. ${ }^{48}$

\section{II}

The civic leaders of Ludlow, a small but historic market town, felt in 1857 that it should have a Crimean trophy. However, the first applicant for a gun in the Marches area appears to have been not Ludlow, but Hereford. On 20 June 1857 the Hereford Times carried an article which asked:
And why should not Hereford, the metropolis of a county which contrib- uted so largely to the Crimean army, and many of whose gallant sons now sleep in that war-desolated peninsular [sic], receive the honour of a trophy? We indeed saw no 'reason why'; and our worthy Mayor took the same view. His Worship therefore made the necessary application to Lord Panmure; and his Lordship, in complying with the request, intimates that he relies on the public spirit and intelligence of the inhabitants of Her- eford, that the gun will be correctly mounted and carefully preserved. A subscription has, therefore, been commenced to defray the expense of the mounting, and any contributions of citizens, willing to promote the same, will be received by the Town Clerk. It is calculated that about $£ 25$ will enable the Corporation to meet all the expenses, if the Great Western Railway Company (as we have no doubt they will) accommodate the city by conveying the gun gratuitously from London to Hereford, as they have done in the instance of other places.

On 21 August 1857 Hereford shops closed for a half-holiday, and a civic procession headed by the mayor, local MP and city councillors moved from the Guildhall to the railway station to collect the newly arrived trophy. From there they progressed, to the music of the Herefordshire Militia Band, around the city and onto the Castle Green, where 'several thousands of persons' watched the cannon's installation in 'the southeast corner of the Green - the muzzle of the gun being pointed over the Castle Mill garden and the river'. The gun was fired three times - the

\footnotetext{
${ }^{46} I L N$, no. 953, 1 Jan. 1859 , p. 22.

${ }^{47}$ We thank J. Partington and the Greenwich Heritage Centre for information and pictures of the memorial.

48 ILN, no. 848, 7 March 1857, p. 203; John Glanfield, Bravest of the Brave: The Story of the Victoria Cross (Stroud, 2005), which also covers the controversy over the metal used.
} 
relatively faint report disappointed the crowd; a 'very elegant and wellmade' tricoloured balloon was released; and the city worthies gathered later in the Council Chamber for a celebratory dinner. The event received an almost full-page spread in the Hereford Times, including a poem written for the occasion. ${ }^{49}$ Many towns and cities elsewhere in the country which acquired Crimean trophies celebrated their arrival with similar pomp and ceremony. ${ }^{50}$

Other local Marches towns followed Hereford's lead. Leominster acquired a Crimean gun, ${ }^{51}$ as did Wrexham and Monmouth. However, some expectations were disappointed. A letter to the Hereford Times lamented that Brecon, even though a garrison town, had not yet sought to obtain a trophy of its own, and declared that it was going to do so; but nothing came of this. And about the same time the Shrewsbury Chronicle waxed indignant at the lack of a cannon for Shrewsbury. The paper was 'somewhat surprised that, while other towns were obtaining from Lord Panmure without the slightest difficulty guns taken in the late Crimean War, no steps have been taken by those in authority in this town to provide a similar trophy from scenes where Shropshire men so highly distinguished themselves'. ${ }^{2}$

In fact neither of the two Shropshire regiments formed part of the Crimean 'Army of the East', and Shrewsbury did not receive a cannon. But the honour of such Shropshiremen as had found their way to the Black Sea was saved by both Bridgnorth and Ludlow, which did. ${ }^{53}$ In Ludlow the mayor, Francis Richard Southern, took the initiative in applying to the War Department for a Russian trophy: the positive response was announced to Ludlow Borough Council at its meeting of 6 August 1857. The councillors 'Resolved unanimously that the Council approved of the course taken by the Mayor and that they accept the gift on behalf of the inhabitants, and undertake the due care and preservation of it.' The gun would be a gift from the War Department, but a subscription was started to defray costs of mounting and maintaining it. A former mayor, Mr Valentine, and the station master, Mr Allen, had meanwhile persuaded the Shrewsbury and Hereford Railway Company to 'convey the gun free of cost from Croydon to Ludlow'. The Railway

\footnotetext{
${ }^{49}$ Hereford Times [hereafter HT], 22 Aug. 1857, p. 8; also HT, 15 Aug., p. 12; 8 Aug., p. 7. 'The Russian gun' was itself signatory of a letter to the $H T$ on 29 Aug. (p. 4), stating that it was a 36-pounder, 9' 7' long, cast in 1836, weighing 3 tons $5 \mathrm{cwt} 1 \mathrm{qr} 14 \mathrm{lb}$, throwing a 36-1b round shot four miles. David Whitehead, The Castle Green at Hereford. A Landscape of Ritual, Royalty and Recreation (Woonton, 2007), pp. 63, 78, is silent on the Crimean cannon.

${ }^{50}$ E.g. Bradford and Bath: The Times, 22 June 1857, p. 11; 10 Sept. 1857, p. 10; ILN, no. 880, 26 Sept. 1857, p. 317.

51 Ludlow Standard (Leominster), 9 April 1943, p. 3, 'Grange cannon removed for munitions: a relic of the Crimean War'; HT, 2 Feb. 2012, p. 6, 'Appeal to solve mystery of missing "Russian" cannon'.

${ }_{52} H T, 15$ Aug. 1857, p. 7; Shrewsbury Chronicle [hereafter SC], 14 Aug. 1857, also quoted by John Hunter, 'Ludlow's "Russian Gun", Country Quest, June 1987.

${ }_{53}$ Bridgnorth: Northgate Museum, Bridgnorth, website: <http://www.bridgnorthmuseum.org.uk/> (accessed 15 Jan. 2011); Shropshire Archives, DA2/709/2/26, n.d. [c.1893]; SC, 4 Dec. 1857.
} 
Company's patriotic decision was very much in line with practice elsewhere in the country, but it may have been facilitated by the fact that the company's then owner, the railway entrepreneur Thomas Brassie, had been the principal contractor for the Grand Crimean Railway built for the Army of the East in the Crimea. ${ }^{54}$

On 25 November 1857 Eddowes Shrewsbury Journal reported that Ludlow's gun, 'This great trophy of national valour', weighing two tons, had duly arrived in the town at 1 o'clock on the previous Saturday, conveyed by the goods train. ${ }^{55}$ 'A vast number of persons have visited the Station, anxious to catch a glimpse of this powerful engine of destruction

.${ }^{56}$ Unlike Hereford, Ludlow's Council appears not to have considered the gun's arrival an occasion for elaborate celebration. But the question of where to site it caused much discussion. Initially a decision was deferred to allow consultation of 'other interests'; $;$ ' then the Borough Council 'Resolved that the space in the Castle Walk on the South Side of the entrance to the Castle be placed at the disposal of the Subscribers to the Russian Gun as a site for the same'. ${ }^{58}$ Three weeks after its arrival in Ludlow, however, the gun was 'brought up from the station, by two powerful horses, and placed in the Market-place'. ${ }^{59}$ It seems that this initial siting made it an obstacle to the market: in February 1858 the Council passed another resolution, 'that the Russian Gun be removed from its present position and placed on the site previously proposed in the Castle Walk'. ${ }^{60}$ This was done two months later. At 'the west end of Castle Street, immediately adjoining the Castle Walk', reported the Hereford Journal, '[a] platform of solid masonry has been raised, on which the gun is erected, surrounded by an iron palisade, and an ornamental chain cable attached to six standards or iron columns, surmounted by a cannon ball'. The Journal thought that the cannon's position, facing the market place, was 'perhaps the most desirable that could have been selected'. ${ }^{61}$ The gun has remained there ever since.

If the leading citizens of Brecon and Shrewsbury were not inspired to seek an official trophy, what was it that moved the worthies of Ludlow? An answer may possibly be found in local politics. Ludlow was a classic 'pocket borough', having two parliamentary seats, long dominated by the earls of Powis. ${ }^{62}$ One of the sitting members was a hero of the Crimean conflict. Lt-Col. The Hon. Percy Egerton Herbert (1822-76), second son of the second earl of Powis and grandson of Robert Clive (of India), also known as 'Hellfire Herbert', had had a very good war.

\footnotetext{
54 Pers. com. Prof. Michael Rosenbaum.

55 Eddowes Shrewsbury Journal [hereafter ESJ, 25 Nov. 1857, also quoted by Hunter, 'Ludlow's'.

56 SC, 27 Nov. 1857, also quoted by Hunter, 'Ludlow's'.

57 Shropshire Archives, LBC Minute Book, 6 August 1857; cp. ESJ and HT, 12 Aug. 1857.

58 LBC Minute Book, 19 Nov. 1857; cf. HT, 21 Nov. 1857.

59 SC, 18 Dec. 1857.

60 LBC Minute Book, 4 Feb. 1858; HT, 6 Feb. 1858.

61 Hereford Journal, 21 April 1858, p. 8.

62 David Lloyd et al. (eds), Victorian Ludlow (Bucknell, 2004), ch. 5.
} 
For his Crimean services Herbert was made a full colonel, aide-de-camp to Queen Victoria, Companion of the Order of the Bath $(\mathrm{CB})$, and received further honours from the Turkish, Sardinian and French governments. ${ }^{63}$ In keeping with Codrington's proposal that senior officers should have Russian trophies of their own, he also became possessor of a small trophy cannon, now displayed in the inner courtyard of Powis Castle. ${ }^{64}$

On his return from the Crimea, Herbert received a rapturous public reception. Welshpool greeted him on his arrival at nearby Powis Castle, on 6 August 1856, with a procession accompanied by cannon-fire and the militia band, and a public dinner, followed two days later by a ball and supper. ${ }^{65}$ Not to be outdone, on 23 August Ludlow arranged a procession through gaily decked streets to a lavish déjeuner, prepared by Mrs Protheroe of the Feathers Hotel in a 'Balaklava tent' on the Castle Green; cannon were brought in for the occasion from nearby Berrington, Lord Rodney's estate. Herbert was presented with a bejewelled memorial sword, specially made and paid for by subscription (and now on display at Powis Castle); during the speeches, the (third) Earl of Powis thanked

the inhabitants and burgesses of Ludlow for the patriotic indulgence which they afforded to my brother [Herbert as a Ludlow MP], enabling him to serve his country in the Crimea. (Cheers.) I must thank them for the wise discernment with which they felt that at the time a soldier could serve ... better at Sebastopol than in Westminster. (Cheers.)

The occasion ended with music and dancing. ${ }^{66}$ Following these 'brilliant example[s]', in September Shrewsbury held an equally elaborate 'Demonstration' for the returned hero and fellow local Crimean officers: another procession and public subscription dinner, completed by fireworks. ${ }^{67}$ Herbert was also honoured by other Marches towns.

The following spring, April 1857, four months before Ludlow Borough Council's resolution approving the mayor's application to Lord Panmure, there was a general parliamentary election. The two Ludlow candidates (unopposed) were Herbert and Beriah Botfield, a local coal magnate. ${ }^{68}$ At the official nomination meeting at the end of March, presided over by the mayor, Herbert's distinguished Crimean service was a prominent theme: the mayor made much of it, and Botfield was fulsome in his praise of his colleague's valour. ${ }^{69}$ Thus the Crimean motif remained important in local civic discourse. While direct

\footnotetext{
63 ODNB, s.v. 'Herbert, Sir Percy Egerton'.

64 We thank Emma Marshall, Assistant House Steward, Powis Castle and Gardens, for information on Herbert and his Crimean cannon.

65 Shropshire Archives, 665/4/339.

66 SC, 29 Aug. 1856; Worcestershire Chronicle, 27 Aug. 1856, p. 3.

67 SC, 29 Aug., 12 Sept. 1856; Shropshire Archives, 665/3/7/16.

68 Lloyd et al. (eds), Victorian Ludlow, p. 104.

69 ESJ, 1 April 1857.
} 
proof is lacking, in all probability the aristocratic presence of Herbert as one of Ludlow's newly re-elected MPs, with his glamorous war record, encouraged Ludlow's mayor to seek a Crimean trophy for the town.

Although most contemporary references suggest public and popular approval of Ludlow's new monument, not everyone was in favour. In 1860 there appeared a book of travels in Shropshire, All Round the Wrekin. On his visit to Ludlow the author, Walter White, was outraged by what he considered the bad taste of the Russian cannon:

The main entrance [to the castle] is . . . an arched gateway ... which gains nothing in picturesque effect by having in front of it one of those stupid trophies from Sebastopol - a Russian gun. It seems to me a mistake to have distributed those ugly things over the land; eyesores in the quiet streets of country towns ... The Greeks, as I have read, used to set up wooden trophies, so that the memory of quarrels should not be too long perpetuated ... .

White was in effect echoing Panmure's sentiment, quoted above, that 'to parade the fruits of our conquest' meant to 'keep open the sores of war after the healing hand of peace has been applied'. But Panmure evidently understood better than White the resonance of the guns in raising public morale in the aftermath of a chaotic and bloody war, and in reflecting the nationalistic patriotism of the Victorian age.

The Crimean trophy guns remained in place throughout the nineteenth century. After the First World War many British towns and cities were offered similar trophies of captured German ordnance: Ludlow acquired a German field gun, which was placed like its Russian predecessor in Castle Walk. ${ }^{71}$ In the Second World War a great many Crimean guns fell victim to the government's drive to collect scrap metal. The Crimean trophies at Bath, Cheltenham, Derby, Glasgow, Lichfield, Portsmouth, Wootton Bassett, to name just a few, were lost in this way; the same fate befell the prize cannon at Hereford, Leominster, Bridgnorth and Wrexham. ${ }^{72}$ Ludlow also answered the call to contribute scrap to the national salvage effort, but it chose not to sacrifice its Russian cannon. Ludlow Council's General Purposes Committee decided that the German gun should be scrapped, along with other redundant metal items, and this was done. ${ }^{73}$ In the reports of the salvage programme no mention was made of the Crimean cannon.

\footnotetext{
70 Walter White, All Round the Wrekin (1860), quoted by Hunter, 'Ludlow's' and by David Lloyd and Peter Klein, Ludlow: A Historic Town in Words and Pictures (Chichester, 1984), p. 102.

${ }^{71}$ Roger Bartlett and Roy Payne, 'Ludlow's German trophy cannon', Ludlow Heritage News, no. 58, summer 2013, pp. 5-6.

72 The ultimate fate of Hereford's several Castle Green guns is unclear. In 1940 the Council decided to scrap them all except the Civil War mortar Roaring Meg (now at Goodrich Castle) and the Russian gun (now disappeared), 'which have historic interest': HT, 31 Aug. 1940, p. 4. Two remain. 73 'Gun to be scrapped', LA, 14 June 1940, p.1. Cf. LA, 12 July 1940, p. 1; Ludlow Standard, 14 June 1940 p. 4, 12 July 1940 p. 6; Ludlow Standard, 19 Dec. 1941, p. 2. Derek Beattie's otherwise excellent The Home Front in Ludlow during the Second World War (Logaston, 2010), pp. 173-5, confuses the German with the Russian gun, an error rectified in his recent South Shropshire's First World War (Little Logaston, 2014), p. 166.
} 


\section{III}

The Russian guns captured at Sevastopol were cast at various Russian foundries and were of various ages. Ludlow's cannon carries clear markers of its identity. The Russian imperial emblem, the doubleheaded eagle, is embossed on its barrel and descriptive data and a record of manufacture are inscribed on its two trunnions. The righthand trunnion identifies it as a 24-pounder frigate gun, weighing $122^{1 / 2}$ poods ( 1 ton $19.4 \mathrm{cwt}$, about $2000 \mathrm{~kg}$.) and cast in 1799 . This was of course more than fifty years before the Crimean War; but during that time technology changed relatively slowly. It is a ship's gun, probably dismounted from a warship and transferred to the new batteries which the Russian authorities hastily constructed on the land side of the base in anticipation of the Allied siege. The Cyrillic letters stamped on the left-hand trunnion give information of origin: ALKSND-ZVD indicates the Aleksandrovskii Zavod or Alexander Foundry, in the town of Petrozavodsk, some 300 miles north of St Petersburg. In this part of Russian Karelia there was timber for charcoal, and plentiful lake and bog ore. Early foundries established there were ephemeral, but under Empress Catherine II a new foundry was created, operational in 1774. In 1786 a newcomer was appointed to run it, the Englishman Sir Charles Gascoigne, and the Ludlow cannon was cast under his management. The further inscription, D. GASKOIN, indicates that at the time he was the foundry's director. Considerable numbers of Crimean trophies came from Gascoigne's foundry, though no complete Gascoigne survey has been attempted. The guns at Monmouth and Ely, for instance, bear his stamp, while that at Newcastle-under-Lyme was cast at Petrozavodsk under Gascoigne's later successor Adam Armstrong. It is an irony that many of the cannon the Russians were using at Sevastopol thus owed their technology to the British, at whom the cannon were fired.

Gascoigne had been recruited to work in Russia by Empress Catherine II (r. 1762-96). ${ }^{74}$ To modernize her empire she imported skills from numerous countries, wherever she found them. She employed Britons in several fields - the architect Charles Cameron built the famous Cameron Gallery for the Catherine Palace outside St Petersburg; Admiral Samuel Greig led her navy to victory over the Swedes. Gascoigne was summoned to revitalize the crucial production of artillery. ${ }^{75}$ (Even the technically most advanced countries of the period,

\footnotetext{
${ }^{74}$ Roger P. Bartlett, Human Capital: The Settlement of Foreigners in Russia 1762-1804 (Cambridge, 1979), pp. 132, 173, 178-9; idem, 'Charles Gascoigne in Russia: A case study in the diffusion of British technology 1786-1806', in A. G. Cross (ed.), Russia and the West in the Eighteenth Century (Newtonville, MA, 1983), pp. 354-67; Anthony Cross, 'By the Banks of the Neva': Chapters from the Lives and Careers of the British in Eighteenth-Century Russia (Cambridge, 1997), passim. See further ODNB, s.v. 'Charles Gascoigne'. Portraits and bust: Cross, 'By the Banks', p. 251; http://www.arthermitage.org/James-Saxon/Portrait-of-Charles-Gascoigne.html; $<$ Google images $>$ Fotografii pamiatnykh mest goroda Luganska et al. (accessed 30 Nov. 2012).

${ }^{75}$ Cross, 'By the Banks', passim.
} 
including Britain, used foreign expertise when advantageous. Thus in 1769 Dutch iron-founders were given charge of the Royal Foundry at Woolwich. ${ }^{76}$ )

Charles Gascoigne (1738-1806), from a Yorkshire family, first made his name as director of the Carron Company works at Falkirk in Scotland, which he managed in 1769-86. Carron Company was one of the period's great pioneering metallurgical and engineering enterprises. ${ }^{77}$ Under Gascoigne it produced the 'carronade', one of the most successful naval gun designs of the time, used by fleets across Europe well into the nineteenth century and to great effect by Nelson's Victory at Trafalgar. The carronade was also sometimes called 'gasconade' after Gascoigne, who developed it and put it into production. ${ }^{78}$ Under Gascoigne, Carron also cast cannon for Russia and other foreign powers. ${ }^{79}$ Ordnance production continued during the following century: some Carron guns were in service with the Allies at Sevastopol. ${ }^{80}$

In 1786 Gascoigne responded to overtures from the Russian government, negotiated by Admiral Greig and his domestic tutor Adam Armstrong, and emigrated to Russia, taking with him men and machine tools and parts. The export of advanced technology and specialist craftsmen from Britain was forbidden by law at this time, and in Russia Gascoigne and Greig were initially boycotted by the British community in St Petersburg. Nevertheless, Gascoigne was extremely successful in his second career (1786-1806), managing both the Petrozavodsk foundries and others near St Petersburg, and establishing the foundry and new town of Lugansk (Ukrainian Luhans'k) in what became the Donbass, in eastern Ukraine: his bust is prominently displayed there.

Charles Gascoigne - Karl Karlovich Gaskoin, as he was known in Russia - was a not insignificant figure in Russian industrial history: although he has been a controversial one in Russian and Soviet historiography, especially of the chauvinistically nationalist Stalin period. The works and foundries which he directed helped to establish Russian engineering and machine-tool making. At Petrozavodsk he was later succeeded by his assistant Adam Armstrong, and by Armstrong's son Roman and other foreigners; and the Petrozavodsk foundries continued to supply weapons to the Russian armed forces. This was still the age of smooth-bore weaponry: rifling first made a decisive impact around the middle of the nineteenth century. Consequently well-made cannon from

76 C. Ffoulkes, The Gun-founders of England. . ., 2nd edn (London, 1969), pp. 65-7; E. Robinson, 'The international exchange of men and machines, 1750-1800', in A. Musson and E. Robinson, Science and Technology in the Industrial Revolution (Manchester, 1969), pp. 216-30.

77 R. H. Campbell, Carron Company (Edinburgh and London, 1961); Brian Watters, Where iron runs like water! A New History of Carron Iron Works, 1759-1982 (Edinburgh, 1998).

78 Watters, Where Iron, pp. 173-9.

79 Roger P. Bartlett, 'Scottish cannon-founders and the Russian navy, 1767-85', Oxford Slavonic Papers, n.s., 10 (1977), pp. 51-72.

80 Reilly, Account, app. III, 'Report on the ordnance used in the siege', pp. 224-5: 32-pounders from Carron, one dated 1856. 
Gascoigne's time still formed part of military and naval stocks. After the Crimean War all belligerents - Russia like Britain and France quickly modernized their artillery and phased out smooth-bore guns; but until then change came slowly. This explains why the British trophies from 1856 included guns half a century old, and why in 1857 Ludlow, along with other British towns and cities, acquired a Russian cannon cast in the eighteenth century by an expatriate British ironmaster. 